\title{
Laudato Si and the Natural Sciences: an Assessment of Possibilities and Limits ${ }^{1}$
}

\section{Celia Deane-Drummond}

University of Notre Dame

\begin{abstract}
This paper will probe the explicit use of the natural sciences in Laudato Si, examining in particular its engagement with environmental science and modern technologies in the light of Catholic social teaching on the environment and broader theological engagement with ecology. What are the particular philosophical presuppositions and theological emphases that this encyclical brings to its analysis of the natural world and how do they inform its specific engagement with ecology and science? I will analyze aspects of contemporary scientific discussion that are particularly relevant for the themes of the encyclical and whose inclusion would have made this an even more convincing document. I will also highlight specific philosophical, scientific and conceptual inconsistencies that have arisen as a result of combining different scientific and theological themes.
\end{abstract}

${ }^{1}$ This article is a substantially revised and expanded version of a keynote address entitled 'The Cry of the Earth: Listening to Laudato Si Through the Medium of Ecotheology', delivered at the Australian Catholic University center in Rome for a symposium entitled Laudate Si: The Greening of the Church, September $21-24^{\text {th }} 2015$. I would like to thank participants at this symposium for feedback, as well as Craig Iffland for helpful editorial comments. 
Ecology is a relatively new science, first introduced by German biologist and philosopher E.H. Haeckel (1834-1919). ${ }^{2}$ The term is derived from the Greek word for home (ô̂kos) and so strikes an explicit resonance with the title of Pope Francis' 2015 encyclical Laudato Si': On Care for our Common Home. The meaning of ecology in the narrower, biological sense refers to the interrelationship between different organisms and their natural environment, otherwise described as 'niche.' Nonetheless, the language of ecology in a theological context means more than simply our home, or even interrelationships; rather, it bears complex and multifaceted social and political connotations. Ecology can refer to the environmental, climate, or conservation sciences or the more explicit science of ecology ${ }^{3}$ or it can signify political or even economic

${ }^{2}$ See discussion in Robert McIntosh, The Background of Ecology: Concept and Theory (Cambridge: Cambridge University Press, 1985) 1-26. McIntosh's historical analysis makes clear how difficult it is to develop a theoretical basis for ecology given the various phenomena it tries to explain, and therefore the standard criteria for science used by philosophers and physics do not apply all that readily to ecology.

${ }^{3}$ For a discussion of the distinction between environmental sciences and ecology, see Celia Deane-Drummond, "Theology and the Environmental Sciences," in Christianity and the Disciplines: The Transformation of the University, ed. Oliver D. Crisp et al. (London: Bloomsbury/T \& T Clark, 2012) 71-84. It should be noted that in theological and humanities literature it is fairly commonplace to find that the terms 'ecology' and 'environment' are used in interchangeable ways. 
'green' agendas that lurk in the background of such empirical changes. If this encyclical is viewed as a contribution to the intersection of theology and ecology, then it is difficult to focus exclusively on the scientific aspects of the encyclical without losing the overall intention of the document as a whole, which is to engage with multiple discourses simultaneously.

In spite of these limitations, I will attempt to analyze the specific use of environmental and other natural sciences in Laudato $S i$, including its treatment of new biotechnologies, though I will situate this in the context of a critical engagement with his theological and philosophical presuppositions. Overall, Pope Francis navigates between more traditional Catholic social teaching on the environment and the more radical suggestions of liberation theologians, such as Leonardo Boff, who, in more recent work, have been influenced by ecological agendas. So, while Pope Francis, in the closing prayer of the encyclical, is prepared to gesture towards the cry of the earth joined with that of the poor $(\S 49)$, Boff himself goes much further in his construction of a theology indebted to James Lovelock's Gaia hypothesis. ${ }^{4}$ This controversial holistic scientific theory of the earth's temperature and gaseous stability set by the sum total of biological organisms, gives value to those organisms that contribute to that stability, and so by

\footnotetext{
${ }^{4}$ Leonardo Boff, Cry of the Earth, Cry of the Poor (Maryknoll: Orbis, 1997) absorbs largely uncritically the Gaia hypothesis, aligning it with stories about the great mother from Andean cultures (12). So, he is happy to declare the earth is a "living superorganism" $(12,16)$, Gaia rendering earth as analogous to a human body $(17)$, and accordingly the Gaia hypothesis "seems very plausible" and is "gaining greater acceptance in both the scientific community and the broader cultural realm" (20).
} 
implication, can interpret human beings as parasitic on planet earth. ${ }^{5}$ It is noteworthy, however, that Boff's name is not even mentioned and it may be because Pope Francis resists the close affiliation with Gaia that Boff seems to illustrate in his work. The treatment of ecological issues in Laudato Si encyclical is a cry from the heart, ${ }^{6}$ bringing a passion that has been informed by his first hand early experience of living at the tip of Argentina and witnessing the drastic melting of Antarctica. ${ }^{7}$

Before getting to the text of the encyclical itself, it is important to note that Pope Francis is deliberately building on the attention to environmental issues of his predecessors, especially in the teaching of Pope Benedict XVI and Pope John Paul II. Although his style is very different, he inherits a substantive theological commitment to engage with ecology even if the recent encyclical moves that commitment from the periphery to the center of papal discourse. Ecological questions were always joined with and to some extent built out of Catholic concerns for social justice. Catholic social thought began to integrate environmental issues into traditional social justice themes,

${ }^{5}$ Celia Deane-Drummond, The Ethics of Nature (Oxford: Wiley/Blackwell, 2004) 162185. Boff does not interpret Gaia in this way, but absorbs Gaian rhetoric uncritically.

${ }^{6}$ Bruno Latour, "The Immense Cry Channeled by Pope Francis," translated by Stephen Muecke, Commentaries on Laudato Si!, edited by Mgr. Beau, College des Bernardins, September 2015, http://www.scribd.com/doc/287005182/Latour-2015-The-ImmenseCry-Channelled-by-Pope-Francis\#scribd, accessed November $4^{\text {th }} 2015$.

${ }^{7}$ Cardinal Óscar Andrés Rodríguez Maradiaga, SDB, “A Conversation with Cardinal Rodríguez: Thoughts on Laudato Si and the Synod", public lecture, University of Notre Dame, November $5^{\text {th }} 2015$. 
amidst wider debates about whether conservation detracted from the concerns of social justice and vice versa. ${ }^{8}$ While this synthetic approach starts off as a small trickle in the 1970s with occasional references to environmental concern in the writing of Pope Paul VI, it had become a significant theme by the pontificates of Pope John Paul II and Pope Benedict XVI. While climate change is rarely mentioned, if at all, in earlier Catholic social thought, Pope Francis joins his immediate predecessors in including in his overview of the global state of affairs a discussion of the social impacts of climate change, including important, but qualified, ethical directives on coal usage ( $\$ 165)$, but not to the extent that it eclipses other environmental problems in the way that has tended to dominate public discussion. I suggest that it is significant that the sequence of issues that he raises for close consideration start with biodiversity loss, then moves to climate change and associated degradations to the earth systems. In other words, he puts a discussion of climate change in the context of the whole system and its functioning, and

\footnotetext{
${ }^{8}$ For the development of environmental concern within Catholic social teaching see, Celia Deane-Drummond, "Joining the Dance: Catholic Social Teaching and Ecology," New Blackfriars 93 no. 1044 (2012) 193-212. The integrated conservation and development projects (ICDP) have come under increasing criticism in terms of their failure to achieve their goals for either the protection of biodiversity or social justice, opening up once again tension between conservation and social justice issues. A full discussion of this issue is outside the scope of this paper, but for a good review of the philosophical issues see, for example, Thaddeus R. Miller, Ben Minteer, Leon-C Malan, "The New Conservation Debate: The View From Practical Ethics", Biological Conservation,
} 144 (2011), 948-957 
describes the human activities that lead to destructive changes on earth in the theological language of sins $(\S 8)$. What is also interesting is how far and to what extent Pope Francis builds his case for an inclusion of ecological themes on this prior dialectic between issues in development and ecology, or if he takes the more radical stance of liberation theologies or eco-theologies, that are more often than not critical of the social and political arrangements and policies of the global north.

His explicit call for a cultural revolution (\$114) could perhaps be seen as that which emerges from the Argentinian school of Latin American theology, which stresses the important insights arising from a theology of the people, and cultural change rather than radical socio-economic transformation. This Argentinian school of thought is also rather more open to the insights of the natural and social sciences and Western philosophy compared with liberation theologies emerging in Latin America that, until Pope Francis was elected, were much more influential globally. ${ }^{9}$ This background is helpful in making sense of why he chose to pay so much attention to environmental sciences and modern technologies in the way that is illustrated below.

In dealing with the difficult and complex issues at the interface of theology and the natural sciences a number of questions rise to the surface. Is Pope Francis accurate in his scientific analysis? What are the philosophical and theological presuppositions that inform his analysis of the science? And in terms of practical consequences of that engagement, does he argue for eco-justice that protects creatures other than humans as

\footnotetext{
${ }^{9}$ Juan Carlos Scannone, "Papa Francesco e La Teologia del Popolo," La Civiltà Cattolica 3930 (2014) 571-590. I am very grateful to Fr Gerard Whelan for giving me access to a fascinating as yet unpublished article.
} 
well as environmental justice, and what is the relationship between them? Are there specific areas of science that he could have profitably covered, given his overall intention to convince his readers that there is an imperative for environmental responsibility? How far is Pope Francis' treatment consistent in the claims that he makes about human relationships with the natural world? These are some of the central questions I intend to treat below.

\section{Ecology and Environmental Science in Laudato Si}

The first chapter of the encyclical is dedicated to a discussion of environmental harms, including climate change. In this section, Pope Francis wants to engage with the broadest audience and readership possible. The pace of climate change caused by human activities has caught the attention of scientists all over the world, so much so that geologists claim that we are living in the age of the Anthropocene. ${ }^{10}$ This is a new moral context where human beings collectively have become subjects of moral scrutiny. What most concerns Pope Francis is the lack of directionality of this overall change, a lack of concern for the common good. The difficulty, of course, is how to bring about more positive changes and what that good might entail. In order to think through that difficulty, Pope Francis has to pay attention to environmental and climate sciences. As a chemist by training, he demonstrates a readiness to move rather more confidently through the scientific discourse compared with his predecessors, so it is significant that so much of this encyclical

${ }^{10}$ This term is not mentioned, though it would have been helpful if it had been included, as I discuss further below. 
includes scientific discussion. At the same time, he communicates in ways that show his clear desire to reach out to non-specialists.

He begins Laudato Si', therefore, with a common experience the world over, namely that of pollution and its impact on health, as well as the loss of beauty in creation such that the older generation laments the loss of once beautiful landscapes. His description of what has happened is put in the starkest of terms: the earth has become "an immense pile of filth" $(\S 21)$. The blame is squarely placed on a "throwaway culture" that does not notice or seem to care about such changes $(\S 16)$. But he quickly moves to a discussion of climate change, and, along with the vast majority of scientists, insists that there is a "solid consensus" on a "disturbing warming" of the climatic system, while acknowledging that each and every climate effect is hard to trace back to specific causes (§23). His support for human induced climate change as being responsible for the bulk of the changes currently experienced globally is certainly in line with the most recent research, and he is careful to connect such changes to specific impacts on livelihoods: drinking water, energy, agriculture, and rising sea levels (§24).

Climate change is an overwhelming problem, often called a 'wicked' one by theorists, as the global political, economic, and scientific issues caught up in climate change seem impossible to solve. The complex issues involved seem intractable. Pope Francis shows that he is aware that climate change as an ethical issue is meaningful to the ordinary person once it is parsed out in terms that have practical impacts on human lives. One of the difficulties that environmental ethicists have repeatedly had in making the climate issue mean something for the ordinary person is that for many it feels disconnected from their everyday experience and their sense of responsibility as moral 
agents. Pope Francis tries to avoid this by highlighting specific environmental problems and showing how they impact the livelihood of everyone who shares "our common home.” Pope Francis gives the acute lack of clean water particular emphasis, partly perhaps because it is easy for most readers to envisage this impact ( $\$ 27-31)$. He builds a narrative about how we have got into the mess that we are in, including drawing on scientific research to make his argument, and then puts forward concrete proposals as to how to make positive changes. Acting responsibly with water usage begins to develop a culture of restraint that then has a knock on effect on overall carbon emissions and thus climate change. Of course in many parts of the world environmental impacts and water shortages or unpredictable weather patterns associated with climate change are already being felt, leading to massive migrations, but often without the recognition of refugee status. Building communities of resilience or adaptation to climate change is an important step, but makes sense in combination with more radical changes in habits of consumption.

Ten paragraphs dedicated to the loss of biodiversity also shows that while he is, in a primary sense, concerned with the particular suffering of human beings, he is also conscious of creaturely suffering that is specifically related to human induced changes. He does not mince his words in laying the blame on human activity: "Because of us thousands of species will no longer give glory to God by their very existence, nor convey their message to us. We have no such right” (\$33). He is correct in this assessment of biodiversity loss, including paying attention to the less well-recognized species that are an integral part of ecosystem functioning. He is also aware of the need to care not just for the conservation of basic resources of soil, water, and air, but considers the welfare of 
animal populations as well through the creation of biological corridors. Conservationists will welcome this message, even if important debates on ecological restoration and translocation of species under threat of extinction are not included. ${ }^{11}$

At the same time, his stance is one of moderation rather than radical change. So, while stressing that those species that are exploited commercially need to have their reproductive habits studied to ensure their survival, Pope Francis does not take the next step and press for a wholesale withdrawal in their use (§35). His overall approach tends to prioritize the protection of the ecosystem rather than individual creatures $(\S 37)$. This is significant in so far as he aims for moderation in the use of other animals, but not total withdrawal from that use. He is conscious of the cultural blindness that gives priority to some issues over others, noting that ignoring the health of marine organisms such as plankton can have an adverse impact on the survival of fish used by human beings for food $(\$ 40)$.

It is important, too, that, like most scientists, he considers humans as part of the natural ecology, rather than separate from it, so both "deteriorate together" (§48). He is critical of attempts to shield ourselves from facing up to the devastation by the creation of artificial safe ecological havens that only benefit the wealthier members of a community (§45). This will be a hard message to absorb for cultures in America and other parts of the global north where a step to becoming ecologically aware can ironically be associated with practices of denial. Ecology, for him, will never mean a prioritization away from

\footnotetext{
11 These are not just matters for the specialist: the historical 'baseline' envisaged for ecological restoration impacts on how humanity perceives its 'common home' and what kind of ecological norms are put in place for future generations. Human settlements even without added complications of climate change have radically altered the composition of island communities; the extent to which we believe this matters will impact on the direction of conservation efforts.
} 
concern for the needy and most excluded human members of the global community (§49). He is also aware of the resilience of ecosystems and the possibility for regeneration (§140) even while using the language of fragile or fragility on multiple occasions (§ 16; 56; 78; 90; 239).

It is worth pausing here to mention his approach to evolutionary science that receives very scant treatment. ${ }^{12}$ In a single passage devoted to this topic, it is clear that for him human beings are not explicable simply through evolutionary processes. It is worth citing this passage in full, since the tension between his approach to natural science and theology comes readily to the fore:

Human beings, even if we postulate a process of evolution, also possess a uniqueness which cannot be fully explained by the evolution of other open systems. Each of us has his or her own personal identity and is capable of entering into dialogue with others and with God himself. Our capacity to reason, to develop arguments, to be inventive, to interpret reality and to create art, along with other not yet discovered capacities, are signs of a uniqueness which transcends the spheres of physics and biology. The sheer novelty involved in the emergence of a personal being within a material universe presupposes a direct action of God and a particular call to life and to relationship on the part of a "Thou" who addresses himself to another "thou". The biblical accounts of creation

\footnotetext{
${ }^{12}$ For a brief discussion of evolution in the Catholic tradition see, Celia DeaneDrummond, "In Adam All Die? Questions at the Boundary of Niche Construction, Community Evolution and Original Sin," in Beyond Galileo: Evolution and the Fall, eds. William Cavanaugh and Jamie Smith (Grand Rapids: Eerdmans, 2016), in press.
} 
invite us to see each human being as a subject who can never be reduced to the status of an object. $(\S 81)$

It would be possible to write a whole article just dealing with this topic! ${ }^{13}$ For the sake of brevity, it is worth noting that Pope Francis resists the evolutionary account as adequate to explain human emergence, while recognizing that humans are still evolved beings. What the 'direct action of God' might entail in relation to this human evolutionary story is left tantalizingly unclear, except that humans are called forth to a particular task and mission that science can never properly address. What he fails to take into account more broadly is the necessity to situate ecological science in the context of evolutionary accounts and vice versa. ${ }^{14}$

\section{Science and New Technologies}

Pope Francis also tries to offer a balanced approach in his assessment of science and technology. On the one hand, he wants to affirm the great gains that contemporary science and technology have wrought in particular areas: medicine, engineering and communications in particular $(\$ 102)$. On the other hand, he is extremely critical of hubristic assertions that presume new technologies will solve the intense environmental challenges of today. Some of these developments are morally ambiguous, since "nuclear

\footnotetext{
${ }^{13}$ I have discussed the way in which Pope Francis' approach to evolution relates to Roman Catholic approaches more generally in Celia Deane-Drummond, "In Adam All Die?"
}

${ }^{14}$ See final section for a brief discussion of why I consider that this is important for ecological analysis and moral theology. 
energy, biotechnology, information technology, knowledge of our DNA" can unleash powers that provide opportunities for domination over the natural world and wholesale destruction of peoples in wartime (§104). He allows for genetic interventions in both plants and animals, including "genetic manipulation by biotechnology for the sake of exploiting the potential present in material reality," but pushes against indiscriminate manipulation (§132). Above all, he seems to think that risks associated with new technologies arise out of their "improper or excessive application," rather than necessarily due to the techniques themselves, and he, like many scientists who argue in favor of genetic modification, claims that such changes are extensions of domestication and other "universally accepted practices" (§133).

His position ignores the possibility of completely new combinations of genes between different natural kinds that are now possible through the development of synthetic biology. He has also not considered here the specific threats to biodiversity through the use of genetically modified crops, or the threat to traditional agriculture by herbicide resistant, self-sterile and other modified crops, or the patenting of traditional indigenous knowledge of the natural world by multinational companies. Indigenous peoples in particular perceive the dominance of trans-national companies in patenting their knowledge or implementing particular genetically modified crops as another form of colonialism. ${ }^{15}$ Given Pope Francis's intention to take account the interests of indigenous peoples, it is a real pity their views were not taken into account in this discussion. The

\footnotetext{
${ }^{15}$ While the ethical issues are not always straight forward, the socio-political agenda is helpful to consider in assessing the ethics of genetic modification. See Celia DeaneDrummond, Ecotheology (London: DLT, 2008) 74-80.
} 
possibility that he was ignorant of their particular views on this topic seems unlikely, unless his perspective on indigenous peoples is reliant on secondary readings through authors such as Boff. ${ }^{16}$

He bemoans a lack of regulation on the development of new technologies, noting that, "nothing ensures that [these technological developments] will be used wisely" (§104). As he suggests, the power of scientific technologies has grown, but our ability to take moral responsibility for their use and development has not (§105). Comparing unfavorably the way humans use resources with that of other natural ecosystems, he notes that "We have not yet managed to adopt a circular model of production capable of preserving resources for present and future generations...limiting the use of nonrenewable resources... reusing and recycling them" $(\S 22)$.

Is the situation quite as bleak as he suggests? It is true that the regulatory framework is patchy and not always adhered to, and some new technologies, including nanotechnologies, escape regulatory frameworks that were put in place following the explosion of powers in genetic engineering. Yet, my own experience as a scientist in the 1980s was that ethical considerations were largely off the agenda in a way that is certainly not the case today, at least in the most 'developed' parts of the world. Part of the

${ }^{16}$ Leonardo Boff idealizes the indigenous traditions, claiming that they are more capable of thinking about the human in relation to the universe (Cry of the Earth, 63). These peoples, along with their ancestral cultures, epitomize an "era of the spirit" (13) and are themselves subject to threat of extermination (86). He fails to discuss the exploitation of indigenous knowledge and 'natural' reserves by biotechnological companies. 
problem is that globally it is hard to enforce regulations, and regulatory structures in emerging economies are often weak, or, worse, corrupt. There are also specific issues associated with the power of transnational corporations that can escape or avoid regulation in jurisdictions where the regulation is weak or absent. The Western world may be problematic in a number of respects, but apart from newer nanotechnologies, regulation of new technologies is reasonably robust.

One of the pressures on Western approaches to environmental regulation is that current legislation, rather than providing specific determinations of what justice demands, habitually relies too much on the use of economic markers as indicators for what is deemed right or wrong, resorting to cost benefit analysis. The common good and the need to take account the wellbeing of future generations is deeply embedded in this encyclical (§156-162), and Pope Francis comments on the ineffectiveness of present legal systems (§142), as well as criticizing a utilitarian calculus rooted in economics. His case could have become stronger by demonstrating more clearly the impoverishment of legal systems as such, and linking positive law with deeper classic aesthetic notions that reinforce an understanding of the common good through the truth and beauty. ${ }^{17}$ But what is particularly interesting is the way his idealization of the laws of nature becomes reinforced by an understanding of their divine origin, that are then interpreted through practical biblical laws (\$68) and point to a normative view of natural laws in their

${ }^{17}$ For a shift towards a greater openness to aesthetics in theories of legal authority, see Mary Ellen O'Connell, “Law, Theology and Interdisciplinarity: A Comparison of Two Inquiries," in New Approaches in Theological Inquiry, eds. Robin Lovin and Joshua Mauldin (Grand Rapids: Eerdmans, 2016), in press. 
relation to positive law and moral law (§69). In other words, there are striking social repercussions of his particular, and, arguably, idealized view of ecological relationships.

He gives a place for scientific research in charting the way forward, even though such initiatives need to be qualified and monitored by a broader ethical and social framework. So, in the first place, he offers praise for those scientists who are dedicated to finding solutions to human induced ecological problems (§34) and states that "greater investment needs to be made in research aimed at understanding more fully the functioning of ecosystems and adequately analyzing the different variables associated with any significant modification of the environment" (§42). Given that the patron saint of ecologists is his mentor, Francis of Assisi, he has warm words to say about ecological research, noting that "ongoing research should also give us a better understanding of how different creatures relate to one another in making up the larger units which today we term 'ecosystems"” $(§ 140)$. He is realistic, therefore, in recognizing the drive for novelty in science, but optimistic in what it might deliver. This is because "human creativity cannot be suppressed. If an artist cannot be stopped from using his or her creativity, neither should those who possess particular gifts for the advancement of science and technology be prevented from using their God-given talents for the service of others" (§131). His empathetic insight into what drives scientific research means that scientists, especially those who are Catholics or who take into account wider societal goals in choosing the topics of their research, will welcome this aspect of his message. So, it is the ends or purposes of that science that qualifies its use.

\section{Values in Science}


Pope Francis adopts what I would term a common sense philosophy based on his own experience and observations of the 'signs of the times.' Science, for him, can never deliver the answer to humanity's biggest questions. So, "it cannot be maintained that empirical science gives a complete explanation of life" (§199). He is suspicious therefore of the elevation of scientific and technocratic method as the sole "epistemological paradigm" through which we understand the world and society $(\S 107)$. In view of that, while he appreciates the role science can play, when technology becomes joined to an ideology of progress in a technocratic paradigm it becomes positively damaging $(\S 101) .{ }^{18}$ He is sharply critical of those who "doggedly uphold the myth of progress and tell us that ecological problems will solve themselves simply with the application of new technology and without any need for ethical considerations or deep change" (§60). In other words, he gives the greatest attention to an analysis of the cultural grip of technology undergirded by an epistemological presumption of the exclusive value of the empirical sciences.

For Francis, the most serious problems facing humanity do not just need a technical solution, but rather a greater understanding of what motivates human beings to live in harmony and peace. Failure to do that amounts to a loss of humanity's moral “compass" (\$200). Like many other philosophers, and an increasing number of scientists, he insists that science and technology are not value free. His belief that "various intentions and possibilities are in play" in technological and scientific developments is

\footnotetext{
${ }^{18}$ Although Pope Francis does not define his meaning of the term the technocratic paradigm, it reflects the often unacknowledged reliance on technology as integral to interpretations of human progress. (\$16).
} 
not spelt out in any specific way, though he could mean epistemological and economic driving forces that help to shape and direct such developments, which themselves may be a response to a more general attachment to consumerism $(\S 114)$. This means that what is required is a "bold cultural revolution," which amounts to a change in philosophy that is encouraged by slowing down and looking at the world around us differently, a return to values of a prior age, and liberation from "unrestrained delusions of grandeur" (ibid.).

What form might such a cultural revolution take? In the first place, he insists on a multidisciplinary approach that includes "an intense dialogue between science and religion” (\$62) and a way of doing science that takes into account other fields of knowledge, "including philosophy and social ethics" (§110). He decries the specialization of the sciences "since each can tend to become enclosed in its own language" leading "to a certain isolation and the absolutization of its own field of knowledge" (\$201). Such dialogue is not just theoretical, for without it environmental challenges cannot be dealt with effectively. Like Pope Benedict XVI, who strongly believed that economics was of our own human making, and so could be reformed, for Pope Francis humanity should not surrender to the conditioning of technology $(\S 110)$ or succumb to the goal of accumulation of data "which eventually leads to overload and confusion, a sort of mental pollution" (§47). "True wisdom," therefore, is the "fruit of self-examination, dialogue and generous encounter between persons” (§47).

In this discussion he treats science and technology together, though in other places he worries more about technological application for specific purposes. There are a number of threads here worth distinguishing. For Pope Francis, the cultural grip of technology, especially new technologies, is married to myths of progress that have been 
around since the enlightenment, but the residue of modernity's scientific positivism still clings to cultural assumptions about what is or is not important forms of knowledge. His critique of technology as being the root cause of environmental problems, rather than religion, is also common among theologians who write in this field, though the situation is likely to be considerably more complicated. ${ }^{19}$ Further, he does not take into account newer waves among scientists that do challenge the epistemic all sufficiency of science, along with recognition of the complex interrelationships that exist between science and technology, such that technological innovations can also trigger new fundamental research. $^{20}$

Those who cast religious belief, especially Christianity, in a negative light in relation to environmental concern have often blamed its anthropocentrism as being largely responsible. ${ }^{21}$ Although he does deal with the issue of anthropocentrism, he oversimplifies his case by associating such philosophy with science and modernity rather than Christianity. Nevertheless, he does show a deliberate stress on the need for dialogue between different religious traditions as well as a particular emphasis on the intrinsic

${ }^{19}$ Celia Deane-Drummond, Sigurd Bergmann and Bronislaw Szerszynski, Technofutures, Nature and the Sacred: Transdisciplinary Perspectives (Farnham: Ashgate, 2015).

${ }^{20}$ See, for example, Tom McCleish, Faith and Wisdom in Science (Oxford: Oxford University Press, 2014).

${ }^{21}$ Lynn White, “The Historic Roots of the Ecological Crisis," Science 155 no. 3767

(1967) 1203-1206. Pope Francis's refusal to admit such a possibility is unfortunate, even if White's claims were somewhat exaggerated, his call for a return to Franciscan spirituality resonates with Pope Francis' position. 
worth of all creatures, not just humans, and their interconnected relationships (§201). So, "because all creatures are interconnected, each must be cherished with love and respect, for all of us as living creatures are dependent on one another" (§42). But what is interesting here is that, like many conservationists, he is also primarily concerned with the worth of ecosystems, which he believes have "intrinsic value independent of their usefulness" (\$140). His rather greater attention to ecosystem value may at least partially explain how he is able to hold together affirmation of the intrinsic worth of all creatures and their instrumental use by humans, though he could have made a much more convincing case in this respect.

For Pope Francis, an environmental ethic will always, nonetheless, look to what humanity needs to be like in order to implement change. And one of the first markers of that is humility, for "once we lose our humility, and become enthralled with the possibility of limitless mastery over everything, we inevitably end up harming society and the environment" (\$224). For him qualified utility of the natural world is the mark of humility, rather than simply withdrawal from any engagement. He points to the failure in dialogue and ideological conflicts, even among those who are involved in various ecological movements. Like other Popes before him, he also stresses the value and the integrity of human life, and he is not prepared to compromise on the significance and value of the human person. Humans will always have pride of place for "Christian thought sees human beings as possessing a particular dignity above other creatures" (\$119).

\section{A Theological Basis for Science and Creation Care}


As one might anticipate, the theological dimension is woven in throughout this encyclical, using common language associated with transcendence as that which is beyond the formulas of mathematics and biology $(\S 11)$. This is part of a deliberate strategy of inclusivity. Yet, the underlying theological elements are vital in order to appreciate the rich underlying tapestry that motivates this encyclical in such a way that it allows him to interpret the deliverances of science in a particular way. There are some predictable elements that put stress on a theology of creation, such as the affirmation of the goodness of different living things as creatures of God. But, rather more contemporary, in the same paragraph, is his insistence on the worth and goodness of "the harmonious ensemble of organisms existing in a defined space and functioning as a system" $(\S 140)$. The clear message of the encyclical that the earth is our common home, a gift of God, while certainly not new for ecotheologians, is, nonetheless, an important message that has a critical significance both in the public sphere and in the Church. Yet, his interpretation of ecological relations as harmonious relations, which seems to emerge from his particular theological commitment to the value of peace, reflects a specific understanding of ecology in terms of stable relationships that is no longer in vogue among ecological scientists, as I will discuss further below. The theological virtues of charity, faith and hope that help build a peaceful society have been the main area of concern for the last three papal encyclicals, but it is the explicit practical expression of these virtues that now finds a home in what could be termed a theological earth charter.

Another theological dimension that is relevant more specifically to scientific work is his belief that science can benefit from religion by encouraging a type of wondrous 
humility that comes from faith. Accordingly, he approvingly references his earlier encyclical on faith, in which he explained how "faith encourages the scientist to remain constantly open to reality in all its inexhaustible richness. Faith awakens the critical sense by preventing research from being satisfied with its own formulae and helps it to realize that nature is always greater" ( $\$ 199$ n141). I would agree that "wonder before the profound mystery of creation" is at its most intense when stirred by religious belief and certainly scientific practitioners who are also religious believers would endorse his stance (ibid.). What is not so clear is how non-believing scientists might receive such statements or whether they are ready to accept that "the gaze of science" will always benefit from faith (ibid.). But at least naming the issue of wonder and awe in relation to science and religious belief can start a conversation.

The virtue of hope is also significant both theologically and for the theme that Pope Francis seeks to address. But this is generously interpreted, so that, inspired by the example of Noah, "all it takes is one good person to restore hope" (\$71). Hope is premised, then, on biblical narratives that showed how the people of Israel hoped, in spite of everything, that "the God who created the universe out of nothing can also intervene in this world and overcome every form of evil” (\$74). But what is different, perhaps, from many other theological works is the inclusion of the virtue of profound joy as mixed in with hope. There are deep and serious issues here, certainly, but the ultimate standing is upbeat, and, at the end of the encyclical he is prepared to say, "let us sing as we go. May our struggles and our concern for this planet never take away the joy of our hope" $(\$ 244)$. It should be added, however, that the explicit systematic theological treatment of ecology is left underdeveloped. While there are both realized and expectant 
eschatological tones in his notion of sublime communion $(\S 89),{ }^{22}$ his focus is on a theology of creation rather than other aspects of systematic thought. I have interpreted the reference to the significance of Christ for creation in the writing of Pope John Paul II as a variant of deep incarnation, ${ }^{23}$ though it has become the focus of far more sustained treatment in contemporary ecotheology. ${ }^{24}$ Pope John Paul II's view is tied to a particular interpretation of Christ as founder of natural law, understood as having a root in the ordering of the natural world as described in the creation story in Genesis. This is rather different from the kind of 'deep incarnation' emerging in contemporary ecotheology that is inspired primarily by the prologue of the Gospel of John. Towards the end of the encyclical, Pope Francis's interpretation of ecological conversion as both a reference to ecology and ultimately to Christ is in my view an implicit deep incarnation, as is his

${ }^{22}$ Denis Edwards, "Sublime Communion: Laudato Si and a Theology of Nature", public lecture presented at the University of Notre Dame, November 2 $2^{\text {nd }}, 2015$.

${ }^{23}$ Deane-Drummond, "Joining the Dance" 193; 196-198.

${ }^{24}$ For a series of essays dealing with this topic, see Incarnation: On the Scope and Depth of Christology, ed. Niels Henrik Gregersen (Minneapolis: Fortress Press, 2015) and for a review of the concept of deep incarnation see Celia Deane-Drummond, "Who on Earth is Jesus Christ? Plumbing the Depths of Deep Incarnation," in Christian Faith and the Earth: Current Paths and Emerging Horizons in Ecotheology, eds. Ernst Conradie, Sigurd Bergmann, Celia Deane-Drummond and Denis Edwards (London: Bloomsbury, 2014) 31-50. 
reference to the Mass on the altar of the world. ${ }^{25}$ A clearer more systematic acknowledgement of deep incarnation would have given a stronger basis for environmental and ecological justice that I turn to next.

\section{Environmental Justice and Eco Justice}

Practical concepts such as ecological conversion and integral ecology emerge from his discussion of climate change, the environmental sciences, and ecology. The International Theological Commission (ITC) used the term 'integral ecology' in their 2009 document on natural law. Cardinal Turkson's mentioned this concept in a number of statements prior to the release of the encyclical, ${ }^{26}$ but the possibility of something like an integral

${ }^{25}$ Denis Edwards, 'Sublime Communion" believes that the Christological element in the encyclical is weak, although it seems to me that it is possible to interpret Laudato $S i$ as a build up to a Christology that is fully inclusive of the material world through his insistence on the cosmic significance of Eucharist. This may also be a deliberate strategy in order to bring on board those of all faiths and none. A full discussion of this topic is outside the scope of this paper. See Celia Deane-Drummond, "Catholic Social Teaching and Ecology: Its Promise and Limits," in Fragile World: Ecology and the Church, ed. William Cavanaugh (Eugene: Wipf and Stock, 2016), in press.

${ }^{26}$ Cardinal Turkson's special influence in crafting this encyclical is well known, and he referred to integral ecology in a number of public addresses and letters prior to the official release of Laudato Si. See, for example, Brian Rowe, “Turkson Talks Papal Encyclical, Integral Ecology at Irish Lecture," National Catholic Reporter, March 10, 
ecology being informative for Catholic social teaching was not on the agenda. In their official writings, Pope Benedict XVI spoke of "integral development" and Pope John Paul II "human ecology," but neither used the term integral ecology. The ITC document makes the following claim

An integral ecology must promote what is specifically human, all the while valuing the world of nature in its physical and biological integrity. In fact, even if man, as a moral being who searches for the ultimate truth and the ultimate good, transcends his own immediate environment, he does so by accepting the special mission of keeping watch over the natural world, living in harmony with it, and defending vital values without which neither human life nor the biosphere of this planet can be maintained (cf. Gen. 2.15). This integral ecology summons every human being and every community to a new responsibility. It is inseparable from a global political orientation respectful of the requirements of the natural law. ${ }^{27}$

2015, accessed October 23, 2015, http://ncronline.org/blogs/eco-catholic/turkson-talkspapal-encyclical-integral-ecology-irish-lecture. Also, Cardinal Turkson, 'Ecology, Justice and Peace: The Perspective of a Global Church', message to participants of Fragile World, Ecology and the Church Conference, de Paul University, 8-12 April 2015. It would be incorrect, however, to assume that Turkson was the originator of the term integral ecology, however influential he might have been in the crafting of the final document.

${ }^{27}$ International Theological Commission, "In Search of a Universal Ethic: A New Look at Natural Law," 2009 §82. For full document see 


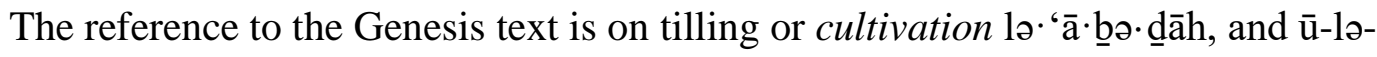
šā-mə-rāh, which means, keeping, tending or caring for the garden in which humanity is placed by God. Both lə· ‘ā'b ’ ’’ dāh and ū-lə-šā-mə-rāh only have one appearance in the Hebrew bible, signifying the special mission for humanity recorded in Genesis that is alluded to in the ITC document. Although the encyclical does reference Genesis 1:15 (§66), one might have expected that it would refer to natural law in which this idea of integral ecology was originally embedded. Pope Francis may have refrained from such use for reasons of political expediency, given how standard interpretations of natural law have been perceived as inflating discriminatory attitudes, which is against the spirit of this encyclical. Even so, traditional Catholic assumptions about natural law are implicit in Laudato Si, coming to the surface at various points, as, for example, in its desire for a universal ethic grounded in a doctrine of creation (\$89-92), its attention to a common humanity and a common good, perceived as rising above individual religious or political persuasions ( $\$ 93-95)$ and in the importance of traditional family life (\$213).

So, while Pope John Paul II preferred the term human ecology, integral ecology also tries to press at the root of the breakdown of relationships. Such ideas help Pope Francis navigate the difficult territory between environmental justice, which is concerned with the disproportionate impact of environmental damage on the poorest of the poor

http://www.vatican.va/roman_curia/congregations/cfaith/cti_documents/rc_con_cfaith_d oc_20090520_legge-naturale_en.html, accessed September $24^{\text {th }} 2015$. 
(§25), and eco-justice, which is concerned with justice for other creaturely kinds. ${ }^{28}$ For him, the loss of cultures is just as serious, or perhaps even more serious, than the disappearance of a species of plant or animal (\$145). The priority for human worth is clear, and he walks on a tightrope between affirming human worth and valuing the natural environment for its own sake. The influence of liberation theology's critique of neo-colonialism comes to the surface in his statement that "the imposition of a dominant lifestyle linked to a single form of production can be just as harmful as the altering of ecosystems" $(\$ 145)$.

Throughout the encyclical the Pope insists that part of the problem is the failure to exercise compassion towards those who are suffering the worst impacts of climate change. Indifference to the suffering of environmental refugees points to a "loss of a sense of responsibility for our fellow men and women upon which all civil society is founded” (\$25). He therefore insists on policy development that will drastically reduce the emission of carbon dioxide. Access to clean water is a basic human right, and because it is essential for survival, has a primary place in relation to other human rights $(\S 30)$. Injustices also relate to the protection of the natural environment, so, in the name of protecting ecosystems such as the Congo basin, individual nations may lose out, mostly because the interests being served in this case are that of multinational corporations rather than the inherent responsibility of public authorities to preserve their country's natural resources $(\S 38)$.

\footnotetext{
${ }^{28}$ For a discussion of the differences between eco-justice and environmental justice, see Celia Deane-Drummond, "Environmental Justice and the Economy: A Christian Theologian's View," Ecotheology 11 no. 3 (2006) 294-310.
} 
Issues of global inequity are therefore pressing, especially disproportional consumption by the richer nations of the world at the expense of the poorest (§51). Yet, at the same time, he does not take his eye off the need to protect ecosystems: "the establishment of a legal framework which can set clear boundaries and ensure the protection of ecosystems has become indispensible; otherwise new power structures based on the techno-economic paradigm may overwhelm not only our politics but also freedom and justice” (§53).

\section{Natural Science and the Earth: Moving Beyond Laudato Si}

Pope Francis wanted his encyclical to be discussed among scientists, and anecdotal evidence is that his message is being heard and widely appreciated. I am also aware that it would be inappropriate to expect this encyclical to cover scientific issues in anything like the detail that would satisfy specialists. Nonetheless, there are important areas of scientific debate that are missed out other than those already mentioned, and I will focus here on scientific concepts with a universal appeal that could have been particularly useful in building his overall argument.

\section{Missing Elements}

By missing elements I mean those areas reasonably well known within the environmental and ecological sciences that would have strengthened the case that Pope Francis is making in garnering scientific evidence for both the need to care for our common home and the steps that have to be in place to implement that care. Of course, there may be others, but these are the ones that are the most striking from my perspective of working in 
this field for the last quarter century. The first missing scientific element concerns different aspects of geology, both with respect to theoretical issues and proposed practical solutions. Current discussion among geologists about the Anthropocene, a term first coined in order to account for the fact that the overall human impact on the planet is now so intense that in historical time it marks a transition from the Holocene. The Anthropocene, if we use the definition of Paul Crutzen, refers to the geological epoch shaped by human activities since the early Industrial Revolution, even though some would argue that it started much earlier. ${ }^{29}$ For the first time in human history, humans have become such a dominant force that they co-determine the state of the earth's crust. The concept of reading history through the geological record is certainly not new; even nineteenth century geologist David Thomas Ansted viewed his work vividly as a reading of the "great stone book of nature." 30 The pages may be crumpled or torn, or even with pages inverted, but the book when re-constructed tells a tale of progression and change, with increasing significance as it approaches the geological era in which we live today. In his discussion of the cultural significance of the Anthropocene, Bronislaw Szerszynski argues that geology is, like medicine, ideographic, dealing with ideas that stem from particulars, rather than physics, which is nomothetic, and deals with general laws. ${ }^{31}$ In order to convey such particularities in a meaningful way, geology makes observed

${ }^{29}$ Paul J. Crutzen and E.F. Stoermer, “The 'Anthropocene,"” International GeosphereBiosphere Programme Newsletter 41 (2000) 17-18.

${ }^{30}$ David Thomas Ansted, The Great Stone Book of Nature (London: Macmillan, 1863).

${ }^{31}$ Szerszynski, Bronislaw, "The End of the End of Nature: The Anthropocene and the Fate of the Human," The Oxford Literary Review 34.2 (2012) 165-184. 
particularities meaningful by a reading of signs, that is, it becomes semiotic. But for the Anthropocene the particular way in which one might read the sign in geology is complicated by the different historical phases of human activity and action. One image of humans in a technological world is Homo faber, humans as maker where the natural world is manipulated for human purposes and ends. In the Anthropocene this becomes superseded by Homo consumens, humanity the consumer, and Homo colossus, a term coined by William Catton that signifies humans as bent on consuming exhaustible resources, including water, thus leading to water scarcity.

How far there might be positive outcomes for humanity in the future rather than negative outcomes is also under discussion. There are a host of ethical issues arising out of different varieties of deliberate manipulation of the planet by human beings. Geoengineering is understood as deliberate use of different technologies in order to attempt to reverse the effects of climate change. ${ }^{32}$ The only time that engineering gets a mention in

${ }^{32}$ Dale Jamieson has discussed the varieties of geo-engineering in his widely discussed book on the philosophy and ethics of climate change. See Dale Jamieson, Reason in a Dark Time (New York: Oxford University Press, 2014) 201-238. While I agree that he is correct to distinguish between carbon capture techniques and those that rely on mechanical mirrors or other experiments in space, to subsume some the formerly labeled geo-engineering techniques under the category of mitigation seems to be just as confusing, since it implies that humans have the powers to continue to benefit from a carbon economy and compensate for any negative 'externalities'. Overall, though, this book is a mirror image of what is presented in this encyclical, an assessment that international agreement is now impossible and all that we can hope for is localized 
the encyclical is a positive one in an allied reference to the beneficial impacts of medicine (§102). But given the severe threats of climate change and the political wrangling in the face of its challenges, it is not surprising that scientists have turned to their own tools of the trade to try and compensate for humanity's lack of restraint. Would Pope Francis have approved of such geo-engineering experiments? Given his resistance to an overextension of technology, the "technocratic paradigm," I have my doubts. Even if this is intended, at least by some scientists, to be a last resort 'emergency' button, the risks associated with such technologies speak of the wielding of power by the few, leading to a complacent attitude and a continuation of business as usual.

A second missing element that would have been helpful in mapping out the extent to which human beings have exceeded the limits of what the earth as a whole can absorb in terms of human impact is related to the practical idea of crossing planetary boundaries. ${ }^{33}$ He speaks, for example, in a number of paragraphs about the climate national frameworks that may or may not be effective. Further, unlike Pope Francis, he presupposes a post-Enlightenment metaphysics that could be argued fosters the very attitudes that have contributed to the environmental problems that now have to be addressed.

${ }^{33}$ The boundaries concept has been used in development literature in order to encourage supporters to envisage more precisely the ways in which the carrying capacity of the earth is under threat. The planetary boundaries concept was originally proposed by a group of earth system and environmental scientists based in Stockholm and led by Johan Rockström, Director of the Stockholm Resilience Center, Stockholm University and Will 
system ( $\$ 23-26)$, the issue of water ( $\$ 27-31)$ and loss of biodiversity ( $332-42)$, but he does not situate this in the context of the whole system. He may be deliberately avoiding Gaia rhetoric, for reasons I have elaborated earlier, but there are scientific alternatives now on offer that are gaining traction. The striking boundaries model envisages the earth as like a circle with specific sectors and boundaries within which humanity can survive in a 'safe operating space' is both immediately recognizable and shows the complexity existing in the earth system. If one planetary boundary is exceeded, it will lead to destabilization in the others. As one might expect, climate change and biodiversity loss, especially genetic diversity rather than functional diversity about which less is known,

Steffen, Australian National University. The lead paper was published in 2009 and is more convincing for many scientists compared with earlier systems models derived from Gaia theory. While it is true that scientific judgment is involved in decisions about what is or is not 'safe,' these scholars have used relatively conservative estimates to come to their conclusions. Further, some of the areas under consideration are simply unknown due to lack of data, for example, the threat of novel entities, or even how far species diversity is reaching a point where it can no longer be functional in terms of biosphere integrity. See Johan Rockström et al., “A Safe Operating Space for Humanity,” Nature 461 no. 7263 (2009) 472-475 and Johan Rockström et al. "Planetary Boundaries: Exploring a Safe Operating Space for Humanity," Ecology and Society 14.2 (2009) 32 http://www. ecologyandsociety.org/vol14/iss2/art32/. See also Will Steffen et al., "Planetary boundaries: Guiding human development on a changing planet," Science 3471259855. DOI: $10.1126 /$ science. 1259855 
are included in the list, but there are other boundaries that are relevant, and missed out in such discussions, including the seven others named: land system change, freshwater use, biochemical flows, ocean acidification, atmospheric aerosol loading, ozone depletion and novel entities. The importance of this concept is that it captures pictorially those areas that are known to have exceeded planetary limits; the nitrogen and phosphorus in biochemical flows are already in the 'red' danger zone as is genetic diversity. Kate Raworth argued that social boundaries needed to be added as well as physical boundaries, thus taking account of social inequities that the earliest planetary boundary models ignored and arriving at a doughnut shaped model that allowed for a safe operating space for all. ${ }^{34}$

Like the concept of the Anthropocene and geo-engineering, such ideas have potentially powerful appeal and force, since they deal with the whole in a way that compensates for the less intuitively satisfying fragmented approach to science that has dominated the last few centuries. Donella Meadows popularized systems theory some years ago. ${ }^{35}$ Systems theory uses computer modeling to envisage social and ecological systems and the relationships between them. A system is "a set of things-people, cells,

\footnotetext{
${ }^{34}$ Kate Raworth, "A Safe and Just Space for Humanity: Can We Live Within the Doughnut?" Oxfam Policy and Practice: Climate Change and Resilience 8 no. 1 (2012) $1-26$.

${ }^{35}$ Donella Meadows was trained in environmental sciences and also was lead author on the influential book Donella Meadows et al., The Limits to Growth: The Report of the Club of Rome's Project on the Predicament of Mankind $2^{\text {nd }}$ edn. (Universe Books, 1974).
} 
molecules, or whatever-interconnected in such a way that they produce their own pattern of behavior over time. ${ }^{\prime 36}$ Systems can change and, importantly, can include both human and non-human elements. A system will often function in a way not intended by a single actor. Thus Meadows: "the most stunning things living things and some social systems can do is to change themselves utterly by creating whole new structures and behaviors. In biological systems the power is called evolution. In human economics it is called technical advance or social revolution. In systems lingo it's called self-organization." ${ }^{37}$

Such an inclusive approach across different levels of organization - the biological, social, and political—is one that would support and reinforce the universal aim of the encyclical, though for such an aim Pope Francis relies heavily on theological language. He would, therefore, place such a systems approach within the framework of divine Providence, rather than presupposing that it could replace a Christian eschatological perspective. The Gaia hypothesis could be viewed as a variant of systems theory for the planet as a whole, though the latter is rather less controversial and also less prone to specific philosophical and religious speculation compared with the Gaian theory. ${ }^{38}$ Pope Francis also avoided variants on this theme that have been used by many of those engaged in religious environmentalism, otherwise known as the new creation story. This perspective weaves in cosmological, evolutionary, and environmental sciences

${ }^{36}$ Donella Meadows, Thinking in Systems: A Primer (White River Junction: Chelsea Green, 2007) 2.

${ }^{37}$ Meadows, Thinking 159.

${ }^{38}$ Celia Deane-Drummond, “Gaia as Science Made Myth: Implications for Environmental Ethics," Studies in Christian Ethics 9.2 (1996) 1-15. 
with insights from the humanities in order to inspire its readers to act responsibly towards the natural world. In spite of its popularity, there are philosophical difficulties in making such a synthesis convincing. ${ }^{39}$ In addition, while Thomas Berry established a rather firmer theological basis for this synthetic approach, ${ }^{40}$ the attempt of the new creation story to be inclusive of all religious traditions means that theological dimensions are somewhat vague, and therefore it tends to encourage a loose form of environmental spirituality. Pope Francis avoids too close an alignment with the new creation story, though it could be argued that his relative lack of attention to the incarnation in the theological elements that are present in the encyclical betrays some of the same weaknesses.

Pope Francis does refer to the work of the twentieth century pioneer Jesuit priest and paleontologist Pierre Teilhard de Chardin. His open understanding of the significance of the mass to the world at large, written in his Mass on the World is in the background of his closing statements in the encyclical (\$236). Teilhard has inspired much of the thinking behind the new creation story, but the fact that Pope Francis refers to the

${ }^{39}$ Lisa Sideris has been particularly critical, and her work has sparked a feisty discussion among a number of ecotheologians and others. See Journal of the Study of Religion, Nature and Culture 9 no. 2 (2015) 136-153 for an essay by Lisa Sideris and responses to her critique, both positive and negative.

${ }^{40}$ See Thomas Berry, The Great Work: Our Way into the Future (Harmony, 1999) and his The Dream of the Earth (Sierra Books, 1988). Berry has influenced eco-feminist scholars such as Heather Eaton and Anne Marie Dalton. For example, see Heather Eaton, ed., The Intellectual Journey of Thomas Berry (Lexington Books, 2015). 
expansive Eucharistic aspects of his mystical vision, rather than the evolutionary aspects of his thought, is significant. This is because Teilhard's views encourage a process theology that is very different from the rather more traditional theology of creation that is embedded in the work of this Jesuit pope. Yet, Teilhard's portrait of Mary as the Eternal Feminine is perhaps in the background as Pope Francis deliberates on her maternal role towards a suffering and broken earth.

Finally, we must note, perhaps especially in light of Pope Francis' engagement with Teilhard, that the encyclical failed to pay sufficient attention to evolutionary theory, and to the issues of creaturely suffering associated with that process. Perhaps this omission was intentional in order to avoid controversy over creationism or other stronger philosophical readings of evolution that press for either an evolutionary ethics, or worse, a new atheism. He does refer to the slow pace of evolution compared with the rapid pace of change in the human sphere (§18). As discussed earlier, he also makes it clear that while evolution is worthy of assent, he finds it necessary for theological reasons to resist an explanation of human origins just in terms of the natural sciences. Evolution is a topic he may well take up elsewhere, but the reason it is relevant for ecological understanding is that it puts in clearer perspective the history of emergence and extinction of myriad and diverse species, along with their even more rapid demise in association with human beings. Indeed, the evolutionary history of human entanglement with other species, along with more recent evolutionary theories that stress cooperation and niche construction would have supported the strong theological case that he makes for human inter- 
dependence, both within human societies and in relationship with other creatures. ${ }^{41}$ While such entanglement does not, on its own, lead to a greater sense of environmental responsibility, at least the knowledge that distinctive human consciousness did not come about alone, but in companion with other creatures, might give pause for deeper reflection before treating such creatures as having purely instrumental worth.

Issues of Consistency

One of the problems in this encyclical, like many other magisterial documents, is one of consistency. While this problem is not as acute as those encyclicals that more obviously have a shared authorship, questions about the status of the human relative to the natural environment persist. So, while welcoming the Franciscan message of care for all creation, including all creatures, romanticism towards the natural world and its harmony reinforced by explicit attention to a theology of creation rather than that of redemption exists in uneasy tension with affirmation of the practice of science, and its more mechanistic interpretation of the natural world, even if that practice has to be duly disciplined by wider cultural and religious values. ${ }^{42}$ Such a tension is often one that eco-theologians

\footnotetext{
${ }^{41}$ I have discussed these aspects in more detail in Celia Deane-Drummond, The Wisdom of the Liminal: Evolution and Other Animals in Human Becoming (Grand Rapids:
} Eerdmans, 2014).

${ }^{42}$ For an excellent discussion of four influential philosophical approaches to nature as dynamic, mechanistic, Romantic and evolutionary, see Louis Caruana, Nature: Its Conceptual Architecture (Bern: Peter Lang, 2014) 25-47. While Francis of Assisi could not be named Romantic as classified according to post-Enlightenment thought, the way the encyclical draws on the perspective of Francis of Assisi does reflect that tradition. 
have to live with if they are going to take the research of environmentalists seriously, unless they put ecology in a different scientific category altogether, for example, treating it as a subversive science. ${ }^{43}$

But it is important to ask, how, precisely, might this new kind of biological science duly disciplined by religious values co-exist with affirmation of the intrinsic value of all creatures? Such details are left tantalizingly unclear, even though the negative movement, that is, what science should not be like, is spelt out. Further, ecologists increasingly put more emphasis on the instability of ecosystems, rather than the idea of harmony, that persisted in the literature for years, largely because of its cultural appeal. ${ }^{44}$ Yet, such ideals persist, and Pope Francis seems to have a similar notion of the relative stability of ecosystems and the need for their protection. Fragility as a concept, where it appears, seems to denote vulnerability to the established order that is reinforced by a traditional theology of creation, rather than a reference to the inherent dynamism of systems and the way they evolve. Taking proper account of evolutionary aspects of the natural world, including creaturely suffering and death, that would have moved away from any notion of fixed harmony, are surprisingly absent. Of course, making instability a focus would have an adverse effect on the ethical thrust of the document, at least insofar as a concession that systems can be inherently unstable makes it more difficult to

\footnotetext{
${ }^{43}$ See Paul Shepard and Daniel McKinley, The Subversive Science: Essays Toward an Ecology of Man (Boston: Houghton Miflin, 1969).

${ }^{44}$ Donald Worster, Nature's Economy: A History of Ecological Ideas, $2^{\text {nd }} e d$. (Cambridge: Cambridge University Press, 1994). I have also discussed the shift in philosophy of ecology in Deane-Drummond, Ethics of Nature 37-38.
} 
identify reasons for valuing particular systems at the expense of others. Of course, stability is present at certain scales of reference and time frames. Newtonian physics is still true even while affirming Einstein's relativity, and something of that trend is true for ecology as both being in equilibrium but also in flux. Climate change, after all, would not be dangerous climate change unless there was an underlying belief that something like a persistent global climate pattern is possible and indeed desirable.

The ecological paradigm does not yet dislodge Pope Francis' attention to human welfare, even though the earth system is the basis for that welfare and therefore, theoretically at least, needs to have higher priority. Leonardo Boff is prepared to make this move, but Pope Francis is not. I believe that Pope Francis is right, but he does not spell this out or deal with the complications that arise in holding two mutually incommensurable ideas together. On the one hand, recognition that the health of the earth has priority, and on the other hand, that human dignity and the value of each and every human being cannot be compromised. His argument that humanity can best solve the problem by changing consumerist lifestyles and over attachment to technology in the richer, Western nations of the world is true to a significant extent, but the scientific data currently available on population change will tell another story. ${ }^{45}$ The battle between those who press for population change as being a primary driver for climate change/sustainability as opposed to those who believe in the primacy of over-

\footnotetext{
${ }^{45}$ See, for example, a very brief survey of the history of total world population in Max Roser, "World Population Growth," Published online at OurWorldInData.org (2015). Retrieved from: http://ourworldindata.org/data/population-growth-vital-statistics/worldpopulation-growth/ [Online Resource].
} 
consumption by relatively few is a false alternative in that both factors need to be taken into account simultaneously. The Vatican has traditionally sided with a resistance to over-consumption by the few because population reduction is sometimes advocated through policies of enforced sterilization or promotion of artificial birth control, each of which are deemed to be morally unacceptable according to Catholic social teaching on human dignity. Some explicit concession to "responsible parenthood" in the context of population concerns in Caritas in Veritate seems to have been dropped here. ${ }^{46}$ Evidence for escalating impacts of growth in total population and the limitation of the overall carrying capacity of the earth ${ }^{47}$ along with the breach of planetary boundaries discussed

${ }^{46}$ In Caritas in Veritate, Pope Benedict XVI discusses population growth, and while he resists blaming such increases as causative of underdevelopment, he also claims that "Due attention must obviously be given to responsible procreation, which among other things has a positive contribution to make to integral human development," followed by later in the paragraph the need "to ensure that parents are suitably prepared to undertake their responsibilities" $(\S 44)$.

${ }^{47}$ World human population is estimated in October 2015 to be 7.28 billion; the maximum number of people the planet is estimated to be able to support is 10 billion. Some scientists have criticized the use of carrying capacity, an ecological estimate of the maximum number in a population that a given environment can support, as rigorously applicable to the human population, because of the complex relationship between human beings and their environment. For an introduction to carrying capacity see Lester Brown, World on the Edge: how to prevent environmental and economic collapse (Washington D.C.: Earthscan, 2011). 
above, cannot be denied in terms of the observed exponential population increase; in this sense, Pope Francis has avoided facing up to well established data.

There are also places where one might have anticipated a sharper critique, given his strong resistance to the epistemological supremacy of science and the needs of the poorest of the poor, but it was not forthcoming. For example, he is somewhat mealy mouthed in his discussion of genetically modified crops. Here he says, "although no conclusive proof exists that GM cereals may be harmful to human beings, and in some regions their use has brought about economic growth which has helped to resolve problems, there remain a number of significant difficulties which should not be underestimated" (§134). This misses out the thrust of much of his earlier arguments about technological dominance and exploitative aspects of technology (§132). Further, developments such as nanotechnology, that could have a huge impact on the natural environment, are only mentioned once, apparently with approval, or at least no negative assessment. His belief that biotechnological interventions could happen "through research uninfluenced by economic interests" is somewhat unrealistic, given the way biotechnology is funded. Further, he believes that legitimate intervention will act on nature only in order "to favor its development in its own line, that of creation, as intended by God" (§132). But would it ever be possible to convince scientists to adhere to such a mandate? And what would it mean?

\section{Conclusions}


Overall, this encyclical is one that takes the natural sciences and associated environmental questions into account in a way that is unprecedented compared with other official magisterial statements. Pope Francis' attention to practical issues of climate change, environmental harms, biodiversity, interconnectedness and ecology more broadly will be welcomed by conservationists and others. His position on ecology, however, is still an idealized one, and his exclusion of evolutionary biology was particularly unfortunate, since if it had been included it might have prompted him to consider more explicit theological issues such as incarnation and redemption as well as an almost exclusive and somewhat romanticized focus on creation theology, even if he avoids the excesses of those influenced by creation spirituality. His stance away from a robust Christology may have been prompted by a move away from a traditional Catholic emphasis on sin and redemption, though that aspect of the tradition's focus on humanity remains anthropocentric. It is also not clear how far he is prepared to let ecological sciences take priority over the human sciences in his discussion; there remains a tension between the two narratives that could have been assisted, for example, by evolutionary accounts that include the ecological concept of niche construction. His more idealistic position on ecology may also reflect a deliberate Eastern Orthodox influence, with its emphasis on the resurrection, given his attention to the concept of sublime communion in this document. Yet even within the paradigm that he is seeking to create, his case could have been made stronger by bringing in at least some reference to scientific ideas such as the Anthropocene, planetary boundaries, and evolutionary theories of niche construction and cooperation. 
I would like, nonetheless, to end on a more positive note. Perhaps one of the greatest contributions that this encyclical will engender is a strong sense that another world really is possible, and the explicit message for scientists is one of both encouragement and restraint. Ecologists and natural scientists more generally will hope that this encyclical will have wider political and social ramifications, especially in the wake of the practical demands of the agreements reached at the international climate summit in Paris in November 2015. 